\title{
EFFECTIVENESS OF MINDFULNESS BASED COGNITIVE THERAPY ON REDUCTION OF NEGATIVE AUTOMATIC THOUGHTS OF DEPRESSIVE PATIENTS
}

\author{
Pegah Farokhzad $^{1^{*}}$ and Tahmineh Yazdanfar ${ }^{2}$ \\ ${ }^{1}$ Dr., Dept. of Psychology, Islamic Azad University, Roudehen, IRAN, \\ dr.pegahfarokhzad@gmail.com \\ ${ }^{2}$ Ms., Islamic Azad University, Roudehen, IRAN, tahminehyazdanfar@gmail.com \\ ${ }^{*}$ Corresponding Author
}

\begin{abstract}
The present research is aimed to study the effectiveness of mindfulness based cognitive therapy on reduction of negative automatic thoughts of depressive patients. It was a semi-experimental research, using pre-test post-test with control group design. The statistical population consists of 20-40 year old patients who were referred to Tehran Psychiatric Institute for depression in 2015. Out of them, on the basis of Cohen's table, 30 patients who had negative automatic thoughts were screened and selected as a sample group and randomly assigned in 2 groups viz. experimental and control groups (15 patients in each group).Participants completed the Automatic Thoughts Questionnaire. To analyze data, covariance analysis was used. Results showed that mindfulness based cognitive therapy reduced the negative automatic thoughts and its components in experimental group in comparison to control group. It can be concluded that mindfulness based cognitive therapy is effective on reduction of negative automatic thoughts and its components (viz. maladjustment, negative expectations, low self-confidence, and hopelessness) in depressive patients.
\end{abstract}

Keywords: Mindfulness, Negative Automatic Thoughts, Depression

\section{INTRODUCTION}

Today, depression is the most prevalent mental disorder of current century and actually is the first mental disorder which has been considered by psychologists and psychiatrists for long. Many studies indicate that females live 20-24 percent of their lives having different levels of depression and this amount is about 10-12 percent in males. Depression is one of the mood disorders which is accompanied by different ranges of sadness, hopelessness and disappointment, loneliness, failure, and feelings of doubt and guilt. This disorder affects individuals' ability in his/her behavior, action, thought and sensation; the individual becomes somehow isolated and withdrawn and his/her relation with others will be decreased. Its range begins from feeling of sadness, inability, inefficacy and unwillingness in life and with time elapse, in higher steps, leads to 
emptiness and suicide (Farahbakhsh, 2009).

Based on Beck cognitive theory, automatic thoughts (which referred to active negative evaluations of people about themselves, around environment and their future), play crucial rule on etiology and of depression. Negative automatic thoughts are situation, unwanted thoughts which comes into one's mind in experience of emotional distresses such as depression and anxiety (Beck, 1967). Depressed people have very pessimistic, negative view about themselves, around environment and future (Beck, 2011). They have more negative prediction about their future and reflect themselves with more negative thoughts and mood; they have lower self-esteem, and mostly use negative words to describe themselves.

Many cognitive therapists believe that emotional and behavioral reactions would be developed by cognitive processes. Therefore, thoughts, beliefs and other cognitive processes are the main determinants of mood and emotion (Hagg, Dyck \& Ernest, 1991; Teasdale, 1997; quoted by Azargoon and Kajbaaf, 2007).

Various psychotherapeutic approaches are introduced for prevention and treatment of depressive disorder. In comprehensive researches related to depressive disorder and suicide, cognitive approaches are known as "golden standards" in psychological interventions (Teasdale, Segal and Williams, 2003). Nowadays, cognitive therapy is experimentally considered as a supported therapy for many disorders such as major depression and strongly is considered as the first line selected treatment for such disorders in a general model (American Psychological Association, 2009).

Cognitive therapy leads to significant increase in approval of positive cognitions and decrease in negative thoughts and risk of depression. Teasdale and Barnard (1993) believed that cognitive therapy in negative automatic thoughts and major beliefs of depressive patients is not solely considered a satisfactory treatment. In 1992, Teasdale and Williams in university of Toronto explained a new approach to treatment, prevention and help depression on the basis of which there is a relationship between cognition, emotion and situational mind and known as mindfulness based cognitive approach (MBCT).

In MBCT as a modern cognitive approach (Teasdale, Sehgal and Williams, 2003), results of training the skills of "controlling attention" showed that mindfulness can affect decreasing negative automatic thoughts. Kaviani, Javaheri and Bahiraie (2009) and Kaviani, Hatami and Javaheri (2012) also showed that mindfulness based cognitive therapy can be effective on reducing negative automatic thoughts of patients.

Mindfulness means attention in a particular, purposeful way at present and devoid of justification (KabatZinn, 2008). Baer (2008) defined mindfulness as an observation devoid of justification about the internal and external progressing process of stimuli and then displaying them. Not-justifying raise mindfulness. When you confront with a difficult physical or emotional states, not justifying about experiences, you will be aware more about what you see, are, and should be. However, this comes from acceptance of pleasurable and painful experiences. Acceptance is not to re-confirm whatever is not morally unacceptable, but accepting the different behaviors. In other words, change is same as acceptance although occurs faster (Azargoon \& Kajbaaf, 2007).

Although the main aim of mindfulness is not relaxation, but observing negative internal events without any justification about them, or physiological arousal cause relaxation. Mindfulness is a skill which allows people at present, perceive events less distressing than what they are. When people would be aware of present, they do not focus their attention toward past or future. Most of mental problems are typically related to the events which have occurred in past or will occur in future. For example, depressive people often feel guilty and regretful about past and anxious people are worried about future problems which cause fear and worry in them (Kabbat-Zinn, 2008; Robbins, 2008; Borkovec, 2007).

Mindfulness is on the basis of training a series of tasks consciously. Any purposeful and conscious exercise can increase capability and ability of information processing system. Mindfulness exercises as primary alarm system can prevent the start of a burst or forthcoming flood. Mindfulness based cognitive therapy is a modern promise in explanation of cognitive-behavioral therapy approach. Mindfulness training requires new meta-cognitive and behavioral strategies to focus on attention, preventing rumination and tendency to worrying responses; and also cause developing new thoughts and reducing unpleasable emotions (Carighead, 2008).

Research done in Iran, showed the effect of mindfulness therapy on reducing depression and negative automatic thought (Azargoon et al., 2007, 2010), depression (Khaleghipour \& Zargar, 2011; Esmaeilian et al., 2013; Omidi, Mohammad khani, Pour Shahbaz \& Dolatshahi, 2008); inefficient attitudes in depression, negative automatic thought, depression and anxiety (Omidi, Mohammadi, Zargar \& Akashe, 2013; Kaviani et al., 2009); and increasing quality of life in depressive patients (Kaviani et al., 2009). Also, other research reported the effect of mindfulness therapy on preventing recurrence of depression in patients (Teasdale et 
al., 2000), preventing the prevalence of suicidal behaviors and how mindfulness skills affect it (Williams et al., 2006; Schulman, 2008; and Chang et al., 2004) and reducing depression in children (Bordrick, 2011).

In view of above, the present research was aimed to study the effectiveness of mindfulness based cognitive therapy on reduction of negative automatic thoughts and its subscales (viz. in-adjustment, negative expectations, low self-esteem and hopelessness) on depressive patients.

\section{METHODOLOGY}

\subsection{Statistical Population, Sample and Sampling Method}

The statistical population of present study consisted of patients in the age range of 20-40 years who referred to Tehran psychiatric institute for having depressive symptoms in 2015. To select sample group, 70 patients who had file in this institute were interviewed and then screening was done using Beck depression inventory and clinical diagnostic interview. Thereafter, 30 patients were selected randomly and finally assigned randomly in two groups: experimental and control groups (15 in each group). The sample size was estimated using Cohen table (with the effect size of $0.5 ; \alpha=0.05$; and test power of 0.76 ).

\subsection{Tests}

\subsubsection{Beck Depression Inventory (BDI)}

This is a self-report questionnaire with 21 items which measure the amount of depression of an individual and is known as a world standard questionnaire. Studies of validity of Beck depression inventory represent a reasonable content and construct validity of the test. Beck. Steer and Garbin (1988) reports the internal consistency of BDI ranging from 0.73 to 0.93 with the average of 0.86 (Alavi et al., 2008). Hatrin, Bohler, Parpal and Mantos (1983) found that BDI has an acceptable reliability; while, Zimerman (1986) showed that test-retest reliability of BDI is 0.64 . Gotlip (1984) reported the alpha coefficient of BDI to be 0.82 and Beck and Steer reported the alpha to be 0.88 . Gerath-Marnat (1990) reported the test-retest reliability of BDI ranging from 0.48 to 0.86 depending on the time interval of the retest and the population. Lightfoot (1985) and Elior (1979) reported the alpha coefficient of 0.87 and test-retest reliability of 0.90 for the test.

\subsubsection{Automatic Thought Questionnaire}

This questionnaire is constructed to evaluate the frequency of negative automatic statements about "self", which these intangible negative statements perform significant role on development, continuity, and treatment of psychological pathology such as depression. Automatic thought questionnaire measures four dimensions of such automatic thoughts including: personal maladjustment and desire for change, negative self-concept and negative expectations, low self-confidence and hopelessness. This questionnaire is worth especially because is formed to measure the cognitive changes of clinical interventions and also to cognitive evaluation of "self-disclosure" in depression. This questionnaire is standardized in a sample of 312 university students. The average age of this sample was 20-22 years with the standard deviation of 4.34 year. These samples were classified to depressive or non-depressive individuals based on Beck Depression Inventory and MMPI. The mean score of automatic thought questionnaire of depressive sample was 79.64 with SD of 22.29. The mean score of non-depressive sample was 48.57 with SD of 10.89. Reliability of this questionnaire has a proper internal consistency with alpha coefficient of 0.97 . The validity of 30 items is selected from a set of 100 items which properly distinguishes the depressive individuals from non-depressive ones (Javaheri, 2004).

\subsection{Procedure}

This research is a quasi-experimental research and pre-test post-test with control group design. Independent variable is mindfulness therapy which is performed on experimental group and its effect is studied on scores of negative automatic thought (dependent variable) of depressive patients and is compared with that of control group. After selecting the sample group, the steps for conducting research were as follow:

Pre-test: Before conducting the therapeutic intervention, automatic thought questionnaire was completed by sample group as a pre-test.

Intervention: The therapeutic intervention was conducted on experimental group for 8 sessions of 120 minutes, while control group did not received any intervention.

Post-test: One week after therapeutic intervention, again both the groups were given the automatic thought questionnaire to be completed. 


\section{RESULTS}

After collecting data, to be confident of homogeneity of variances, after primary matching of the two groups of experimental and control, the Kolmogorov-Smirnoff and Leven test, and homogeneity of regression gradients have been assessed for the studied variables. Then, to analyze obtained data and to test the hypotheses, descriptive statistics method (mean and standard deviation, etc.) and inferential statistics method (covariance analysis) have been used. Descriptive statistical indexes of both the groups in negative automatic thoughts and its dimensions on the two steps of pre-test and post-test are presented in table 1.

Table 1. Descriptive Indexes of Negative Automatic Thoughts and is Dimensions

\begin{tabular}{|c|c|c|c|c|c|c|c|c|c|}
\hline Groups & Variables & Mean & SD & $\mathbf{S}$ & $\mathrm{K}$ & k-s & Sig. & Leven & Sig. \\
\hline $\begin{array}{l}\text { Exp. } \\
(\mathrm{N}=12)\end{array}$ & $\begin{array}{l}\text { Maladjustment (pre- } \\
\text { test) } \\
\text { Maladjustment (post- } \\
\text { test) }\end{array}$ & $\begin{array}{l}32.06 \\
30.53\end{array}$ & $\begin{array}{l}3.692 \\
3.270\end{array}$ & $\begin{array}{l}-0.198 \\
-0.622\end{array}$ & $\begin{array}{l}-0.620 \\
-0.226\end{array}$ & $\begin{array}{l}0.477 \\
0.607\end{array}$ & $\begin{array}{l}0.997 \\
0.885\end{array}$ & 3.051 & 0.092 \\
\hline $\begin{array}{l}\text { Control } \\
(\mathrm{N}=12)\end{array}$ & $\begin{array}{l}\text { Maladjustment (pre- } \\
\text { test) } \\
\text { Maladjustment (post- } \\
\text { test) }\end{array}$ & $\begin{array}{l}31.40 \\
32.06\end{array}$ & $\begin{array}{l}3.541 \\
3.326\end{array}$ & $\begin{array}{l}0.476 \\
0.645\end{array}$ & $\begin{array}{l}-0.537 \\
-0.246\end{array}$ & $\begin{array}{l}0.820 \\
0.676\end{array}$ & $\begin{array}{l}0.513 \\
0.750\end{array}$ & $(1,28)$ & \\
\hline $\begin{array}{l}\text { Exp. } \\
(\mathrm{N}=12)\end{array}$ & $\begin{array}{l}\text { Neg. expectations } \\
\text { (pre-test) } \\
\text { Neg. expectations } \\
\text { (post-test) }\end{array}$ & $\begin{array}{l}28.06 \\
26.66\end{array}$ & $\begin{array}{l}3.575 \\
0.477\end{array}$ & $\begin{array}{c}0.273 \\
-0.065\end{array}$ & $\begin{array}{l}0.220 \\
0.433\end{array}$ & $\begin{array}{l}0.708 \\
0.756\end{array}$ & $\begin{array}{l}0.698 \\
0.617\end{array}$ & 3.181 & 0.085 \\
\hline $\begin{array}{l}\text { Control } \\
(\mathrm{N}=12)\end{array}$ & $\begin{array}{l}\text { Ne. expectations } \\
\text { (pre-test) } \\
\text { Neg. expectations } \\
\text { (post-test) }\end{array}$ & $\begin{array}{l}28.33 \\
29.13\end{array}$ & $\begin{array}{l}2.716 \\
2.531\end{array}$ & $\begin{array}{l}0.457 \\
0.346\end{array}$ & $\begin{array}{l}-0.099 \\
-0.409\end{array}$ & $\begin{array}{l}0.576 \\
0.540\end{array}$ & $\begin{array}{l}0.894 \\
0.932\end{array}$ & $(1,28)$ & \\
\hline $\begin{array}{l}\text { Exp. } \\
(\mathrm{N}=12)\end{array}$ & $\begin{array}{l}\text { Low Self-confidence } \\
\text { (pre-test) } \\
\text { Low self-confidence } \\
\text { (post-test) }\end{array}$ & $\begin{array}{l}30.93 \\
29.66\end{array}$ & $\begin{array}{l}3.972 \\
3.265\end{array}$ & $\begin{array}{l}0.838 \\
0.030\end{array}$ & $\begin{array}{l}0.091 \\
0.423\end{array}$ & $\begin{array}{l}1.005 \\
0.488\end{array}$ & $\begin{array}{l}0.264 \\
0.971\end{array}$ & 3.099 & 0.089 \\
\hline $\begin{array}{l}\text { Control } \\
(\mathrm{N}=12)\end{array}$ & $\begin{array}{l}\text { Low self-confidence } \\
\text { (pre-test) } \\
\text { Low self-confidence } \\
\text { (post-test) }\end{array}$ & $\begin{array}{l}31.33 \\
32.06\end{array}$ & $\begin{array}{l}4.805 \\
4.300\end{array}$ & $\begin{array}{l}-0.544 \\
-0.332\end{array}$ & $\begin{array}{l}-0.607 \\
-0.257\end{array}$ & $\begin{array}{l}0.601 \\
0.462\end{array}$ & $\begin{array}{l}0.863 \\
0.983\end{array}$ & $(1,28)$ & \\
\hline $\begin{array}{l}\text { Exp. } \\
(\mathrm{N}=12)\end{array}$ & $\begin{array}{l}\text { Hopelessness (pre- } \\
\text { test) } \\
\text { Hopelessness (post- } \\
\text { test) }\end{array}$ & $\begin{array}{l}26.80 \\
25.06\end{array}$ & $\begin{array}{l}2.808 \\
2.250\end{array}$ & $\begin{array}{r}0.102 \\
-0.095\end{array}$ & $\begin{array}{l}-0.570 \\
-0.582\end{array}$ & $\begin{array}{l}0.536 \\
0.494\end{array}$ & $\begin{array}{l}0.937 \\
0.968\end{array}$ & 3.894 & 0.058 \\
\hline $\begin{array}{l}\text { Control } \\
(\mathrm{N}=12)\end{array}$ & $\begin{array}{l}\text { Hopelessness (pre- } \\
\text { test) } \\
\text { Hopelessness (post- } \\
\text { test) }\end{array}$ & $\begin{array}{l}26.40 \\
27.60\end{array}$ & $\begin{array}{l}2.613 \\
2.414\end{array}$ & $\begin{array}{l}0.353 \\
0.720\end{array}$ & $\begin{array}{c}-0.255 \\
0.416\end{array}$ & $\begin{array}{l}0.881 \\
0.649\end{array}$ & $\begin{array}{l}0.419 \\
0.794\end{array}$ & $(1,28)$ & \\
\hline $\begin{array}{l}\text { Exp. } \\
(\mathrm{N}=12)\end{array}$ & $\begin{array}{l}\text { Neg. automatic } \\
\text { thought } \\
\text { (pre-test) } \\
\text { Neg. automatic } \\
\text { thought } \\
\text { (post-test) }\end{array}$ & $\begin{array}{l}117.87 \\
111.93\end{array}$ & $\begin{array}{l}5.208 \\
4.712\end{array}$ & $\begin{array}{l}0.644 \\
0.322\end{array}$ & $\begin{array}{r}0.135 \\
-0.266\end{array}$ & $\begin{array}{l}0.864 \\
0.557\end{array}$ & $\begin{array}{l}0.444 \\
0.916\end{array}$ & 1.844 & 0.185 \\
\hline $\begin{array}{l}\text { Control } \\
(\mathrm{N}=12)\end{array}$ & $\begin{array}{l}\text { Neg. automatic } \\
\text { thought } \\
\text { (pre-test) } \\
\text { Neg. automatic } \\
\text { thought (post-test) }\end{array}$ & $\begin{array}{l}117.47 \\
120.87\end{array}$ & $\begin{array}{l}6.759 \\
6.545\end{array}$ & $\begin{array}{l}-0.188 \\
-0.322\end{array}$ & $\begin{array}{l}-0.866 \\
-0.337\end{array}$ & $\begin{array}{l}0.643 \\
0.527\end{array}$ & $\begin{array}{l}0.802 \\
0.944\end{array}$ & $(1,28)$ & \\
\hline
\end{tabular}

Based on the table, the mean scores of maladjustment, negative expectations, low self-confidence and negative automatic thought of the two groups are not very different in pre-test; while in post-test, the mean scores of negative expectations, low self-confidence and negative automatic thought is prominently decreased which might be the effect of mindfulness based cognitive therapy on promoting negative automatic thoughts and its dimensions. The amount of Kurtosis and skew are in the normal range and shows 
the normal distributions of scores.

On the other hand, table 1 shows that the amounts of Kolmogorov-Smirnoff comparing to the significance level which are all more than 0.05 , indicate the normal data distributions. Also, results of Leven test in this table, confirm the normality of data distributions.

To use analysis of covariance in order to study the statistical hypotheses, in spite of Kolmogorov-Smirnoff and Leven Tests, pre assumption of homogeneity of regression gradients should be established as well. Tables 2 and 3 indicate the results of this pre assumption in negative automatic thoughts and its dimensions.

Table 2. Results of Statistical Analysis of Interaction between Groups and Pre-test to Study Homogeneity of Regression Gradient in Negative Automatic Thoughts

\begin{tabular}{|l|c|c|c|c|c|}
\hline \multicolumn{1}{|c|}{ Source } & SS & df & MS & F & Sig. \\
\hline Groups & 1.432 & 1 & 1.432 & 0.337 & 0.567 \\
Pre-test & 709.325 & 1 & 709.325 & 166.674 & 0.000 \\
Groups * Pre-test & 5.836 & 1 & 5.836 & 1.371 & 0.252 \\
Error & 110.650 & 26 & 4.256 & & \\
Total & 407978 & 30 & & & \\
\hline
\end{tabular}

Table 2 shows that there is an interaction between groups and pre-test in negative automatic thoughts. Considering the amount of significance level $(0.252)$ which is more than 0.05 , it can be confidently stated that the regression gradient in this variable is homogeneous.

Table 3. Results of Statistical Analysis of Interaction between Groups and Pre-test to Study Homogeneity of Regression Gradients in Dimensions of Negative Automatic Thoughts

\begin{tabular}{|c|c|c|c|c|c|c|}
\hline Source & Dependent Variable & SS & $\mathrm{df}$ & MS & $\mathrm{F}$ & Sig. \\
\hline \multirow{4}{*}{$\begin{array}{l}\text { Group* } \\
\text { Pre-test } \\
\text { Maladjustment }\end{array}$} & Maladjustment (post-test) & 15.997 & 2 & 7.999 & 3.532 & 0.055 \\
\hline & Neg. expectations (post-test) & 0.246 & 2 & 0.123 & 0.134 & 0.875 \\
\hline & Low self-esteem (post-test) & 0.793 & 2 & 0.397 & 0.359 & 0.703 \\
\hline & Hopelessness (post-test) & 1.355 & 2 & 0.677 & 0.534 & 0.595 \\
\hline \multirow{4}{*}{$\begin{array}{l}\text { Group* } \\
\text { Pre-test } \\
\text { Negative } \\
\text { Expectations }\end{array}$} & Maladjustment (post-test) & 4.312 & 2 & 2.156 & 1.904 & 0.185 \\
\hline & Neg. expectations (post-test) & 0.268 & 2 & 0.134 & 0.292 & 0.596 \\
\hline & Low self-esteem (post-test) & 0.531 & 2 & 0.265 & 0.480 & 0.497 \\
\hline & Hopelessness (post-test) & 1.939 & 2 & 0.968 & 1.528 & 0.232 \\
\hline \multirow{4}{*}{$\begin{array}{l}\text { Group* } \\
\text { Pre-test } \\
\text { Low } \\
\text { Self-esteem }\end{array}$} & Maladjustment (post-test) & 4.997 & 2 & 2.498 & 1.103 & 0.353 \\
\hline & Neg. expectations (post-test) & 0.334 & 2 & 0.167 & 0.182 & 0.835 \\
\hline & Low self-esteem (post-test) & 6.715 & 2 & 3.358 & 3.037 & 0.073 \\
\hline & Hopelessness (post-test) & 1.344 & 2 & 0.672 & 0.529 & 0.598 \\
\hline \multirow{4}{*}{$\begin{array}{l}\text { Group* } \\
\text { Pre-test } \\
\text { Hopelessness }\end{array}$} & Maladjustment (post-test) & 5.626 & 2 & 2.813 & 1.242 & 0.312 \\
\hline & Neg. expectations (post-test) & 0.449 & 2 & 0.255 & 0.245 & 0.785 \\
\hline & Low self-esteem (post-test) & 0.651 & 2 & 0.326 & 0.295 & 0.748 \\
\hline & Hopelessness (post-test) & 7.800 & 2 & 3.900 & 3.073 & 0.071 \\
\hline \multirow{4}{*}{$\begin{array}{l}\text { Group* } \\
\text { Pre-test } \\
\text { Maladjustment } \\
{ }^{*} \text { Negative } \\
\text { expectations* Low } \\
\text { self-esteem } \\
\text { Hopelessness }\end{array}$} & Maladjustment (post-test) & 0.531 & 2 & 2.766 & 1.221 & 0.318 \\
\hline & Neg. expectations (post-test) & 0.353 & 2 & 0.176 & 0.192 & 0.827 \\
\hline & Low self-esteem (post-test) & 0.467 & 2 & 0.234 & 0.211 & 0.812 \\
\hline & Hopelessness (post-test) & 1.297 & 2 & 0.648 & 0.511 & 0.608 \\
\hline
\end{tabular}


Table 3 shows that considering the amounts of significance level which are all more than 0.05 , the interaction between groups, dependent variables and pre-test are not significant; therefore, it can be confidently stated that there is not significant interaction between pre-test and therapeutic intervention in dimensions of negative automatic thoughts and the regression gradients of these variable is homogeneous. So, the analyses of variance can be confidently continued.

Hypothesis 1: Mindfulness based cognitive therapy can reduce the negative automatic thoughts in depressive patients.

Table 4. Results of Covariance Analysis to Study Effect of Mindfulness on Negative Automatic Thoughts

\begin{tabular}{|l|c|c|c|c|c|c|}
\hline \multicolumn{1}{|c|}{ Source } & SS & df & MS & F & Sig. & Eta \\
\hline Negative automatic thoughts & 794.180 & 1 & 794.180 & 184.080 & 0.000 & 0.872 \\
Groups & 646.016 & 1 & 646.016 & 149.738 & 0.000 & 0.847 \\
Error & 116.487 & 27 & & & & \\
Total & 407978 & 30 & & & & \\
\hline
\end{tabular}

Table 4 indicate that after modifying the pre-test scores, there is a significant effect between group subjects $(\mathrm{F}=149.738, \mathrm{p}=0.000)$. Results show that scores of experimental group are significantly decreased in comparison to control group. Eta coefficients state that \%84.7 of changes in negative automatic thoughts in experimental group is explained by mindfulness training. On the other hand, the relationship between scores of pre-test and post-test denote that $87.2 \%$ of pre-test is important in explanation of post-test scores. This result is indicated in the figure below:

Estimated Marginal Means of MEASURE_1
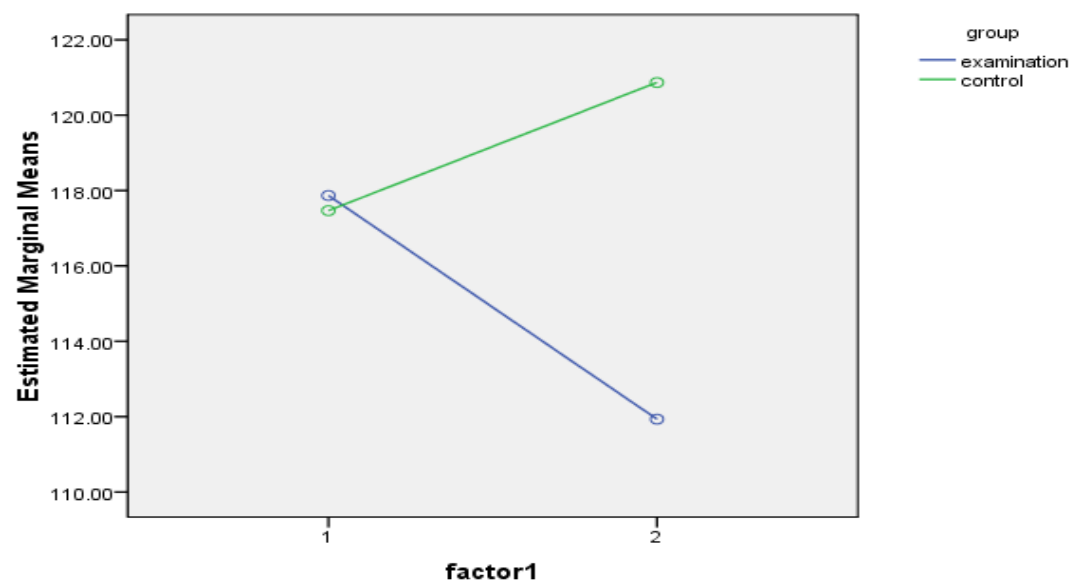

Fig. 1: Changes of Negative Automatic Thoughts of Patients in both Groups in Pre-test and Post-test

As fig. 1 shows, the scores of negative automatic thoughts are prominently decreased in experimental group but in control group the changes are in a way that the negative automatic thoughts are increased.

Hypothesis 2: Mindfulness based cognitive therapy can reduce the dimensions of negative automatic thoughts in depressive patients.

Table 5. Results of Covariance Analysis to Study Effect of Mindfulness on Dimensions of Negative Automatic Thoughts

\begin{tabular}{|l|l|c|c|c|c|c|c|}
\hline Source & Dependent Variables & SS & df & MS & F & Sig. & Eta \\
\hline \multirow{2}{*}{$\begin{array}{l}\text { Maladjustment } \\
\text { (pre-test) }\end{array}$} & Maladjustment (post-test) & 230.365 & 1 & 230.365 & 107.288 & 0.000 & 0.817 \\
\cline { 2 - 8 } & $\begin{array}{l}\text { Neg. expectations (post- } \\
\text { test) }\end{array}$ & 0.443 & 1 & 0.443 & 0.603 & 0.445 & 0.025 \\
\cline { 2 - 8 } & Low self-esteem (post- & 0.122 & 1 & 0.122 & 0.090 & 0.767 & 0.004 \\
\hline
\end{tabular}


IJASOS- International E-Journal of Advances in Social Sciences, Vol.II, Issue 4, April 2016

\begin{tabular}{|c|c|c|c|c|c|c|c|}
\hline & test) & & & & & & \\
\hline & Hopelessness (post-test) & 2.975 & 1 & 2.975 & 2.498 & 0.127 & 0.094 \\
\hline \multirow{4}{*}{$\begin{array}{l}\text { Negative } \\
\text { expectations } \\
\text { (pre-test) }\end{array}$} & Maladjustment (post-test) & 0.907 & 1 & 0.907 & 0.422 & 0.522 & 0.017 \\
\hline & $\begin{array}{l}\text { Neg. expectations (post- } \\
\text { test) }\end{array}$ & 196.019 & 1 & 196.019 & 266.990 & 0.000 & 0.918 \\
\hline & $\begin{array}{l}\text { Low self-esteem (post- } \\
\text { test) }\end{array}$ & 0.985 & 1 & 0.985 & 0.727 & 0.402 & 0.029 \\
\hline & Hopelessness (post-test) & 0.459 & 1 & 0.459 & 0.386 & 0.540 & 0.016 \\
\hline \multirow{4}{*}{$\begin{array}{l}\text { Low self- } \\
\text { esteem } \\
\text { (pre-test) }\end{array}$} & Maladjustment (post-test) & 3.334 & 1 & 3.334 & 1.553 & 0.225 & 0.061 \\
\hline & $\begin{array}{l}\text { Neg. expectations (post- } \\
\text { test) }\end{array}$ & 0.057 & 1 & 0.057 & 0.078 & 0.783 & 0.003 \\
\hline & $\begin{array}{l}\text { Low self-esteem (post- } \\
\text { test) }\end{array}$ & 317.492 & 1 & 317.492 & 234.318 & 0.000 & 0.907 \\
\hline & Hopelessness (post-test) & 0.370 & 1 & 0.370 & 0.310 & 0.583 & 0.013 \\
\hline \multirow{4}{*}{$\begin{array}{l}\text { Hopelessness } \\
\text { (pre-test) }\end{array}$} & Maladjustment (post-test) & 0.001 & 1 & 0.001 & 0.000 & 0.982 & 0.000 \\
\hline & $\begin{array}{l}\text { Neg. expectations (post- } \\
\text { test) }\end{array}$ & 0.570 & 1 & 0.570 & 0.077 & 0.783 & 0.003 \\
\hline & $\begin{array}{l}\text { Low self-esteem (post- } \\
\text { test) }\end{array}$ & 0.530 & 1 & 0.530 & 0.039 & 0.845 & 0.002 \\
\hline & Hopelessness (post-test) & 99.979 & 1 & 99.979 & 83.968 & 0.000 & 0.778 \\
\hline \multirow[t]{4}{*}{ Groups } & Maladjustment (post-test) & 29.960 & 1 & 29.960 & 13.953 & 0.001 & 0.368 \\
\hline & $\begin{array}{l}\text { Neg. expectations (post- } \\
\text { test) }\end{array}$ & 36.662 & 1 & 36.662 & 49.936 & 0.000 & 0.675 \\
\hline & $\begin{array}{l}\text { Low self-esteem (post- } \\
\text { test) }\end{array}$ & 30.236 & 1 & 30.236 & 22.315 & 0.000 & 0.482 \\
\hline & Hopelessness (post-test) & 56.050 & 1 & 56.050 & 47.074 & 0.000 & 0.662 \\
\hline
\end{tabular}

On the basis of table 5, there are differences between experimental and control groups in Maladjustment, negative expectations, low self-esteem and hopelessness and the scores show that these dimensions in experimental group are significantly decreased comparing to control group. Eta coefficients show that \%36.8 of changes of maladjustment, \%67.5 of changes of negative expectations, $\% 48.2$ of changes of low selfesteem and \%66.2 of changes of hopelessness in experimental group are explained by mindfulness training. Also, the relationship between scores of pre-test and post-test indicate that \%81.7 of pre-test scores of maladjustment, \%91.8 of pre-test score of negative expectations, \%90.7 of pre-test scores of low selfesteem and $\% 77.8$ of pre-test scores of hopelessness are important in explanation of post-test scores.

\section{DISCUSSION}

The present research was aimed to study the effectiveness of mindfulness based cognitive therapy on negative automatic thoughts of depressive patients. Results showed that training sessions of mindfulness based cognitive therapy could prominently reduce the automatic thoughts of patients during the intervention.

As shown in previous researches, MBCT skills training as a modern cognitive approach on controlling attention can be effective in reducing the negative automatic thoughts (Teasdale, Segal and Williams, 2003; Kaviani, Javaheri and Bahiraiee, 2009).

Moreover, obtained results of the present research are consistent with the results of previous researches in Iran and other countries. For example, studies by Azargoon et al. (2007 \& 2010); Khalegi pour \& Zargar (2011); Esmailian et al. (2013); Omidi, Mohammad Khani, Pour Shahbaz \& Dolatshahi (2008); Omidi, Mohammadi, Zargar and Akasheh (2013); and Kaviani et al. (2009) in Iran showed that mindfulness therapy is effective on decreasing depression, anxiety, negative automatic thoughts, inefficient attitudes and 
increasing quality of life. Also, studies by Teasdale et al. (2000); Williams et al. (2006); Schulman (2008); Chang et al. (2004); and Broderick (2011) all confirmed that mindfulness based cognitive therapy is effective on decreasing depression, negative mood, hopelessness and many other states which has crucial role in tendency to negative automatic thoughts.

These findings show that changing of the negative automatic thoughts and gaining cognitive skills could probably involve in preventing recurrence of depression. In fact, theoretically, MBCT could increase the preventive effect of the intervention (Seigle et al., 1999). As it is mentioned in earlier texts, actually it seems that mindfulness can be effective by training the attention control (Teasdale et al., 2000). According to this theory, our mind mostly interprets the events which occur and cause the consistent reactions and emotions. In people who volunteer negative automatic thoughts, mind continuously goes toward the negative and unpleasant thoughts which itself perpetuate depression and anxiety.

Mindfulness therapy is one of the modern approaches which modify, control and process the thoughts. In this therapeutic method, the individual's thoughts are experienced as mental events, and concentration and attention on self would be used as a devise for living in present time. The patients will be trained to discontinue the negative automatic thoughts cycle and intervene with their negative thoughts. Training the flexibility of attention, mental enrichment, discontinuing rumination, reforming the incorrect positive and negative beliefs, and also challenging with negative beliefs related to emotions leads to decreasing depression and negative automatic thoughts.

Training mindfulness requires learning meta-cognitive and new behavioral strategies to concentrate on attention, preventing rumination and tendency to worrying responses; it also leads to developing new thoughts and decreasing unpleasable emotions (Carighead, 2008). Such conditions could be effective in reducing the negative automatic thoughts as well.

Therefore, referred to previous researches, it could be concluded that mindfulness based cognitive therapy is related to decreasing negative mood, depression, anxiety, distressing and negative thoughts, hopelessness and negative emotions. So, based on the results of present research and effectiveness of mindfulness on decreasing negative automatic thoughts, using this method could be proposed to clinicians for depressive patients.

\section{REFERENCE LIST}

American Psychiatric Association (2009). Treatment of patients with panic disorder (2 ${ }^{\text {nd }}$ Ed.). APA Practice Guidelines.

Azargoon, H. \& Kajbaaf, M.B. (2010). Effectiveness of mindfulness training on decreasing inefficient attitudes and automatic thoughts of depressive students of Isfahan University. Bimonthly Journal of Scholar Behavior, No. 53.

Azargoon, H.; Kajbaaf, M.B.; Molavi, H. \& Abedi, M.R. (2007). Effectiveness of mindfulness training on decreasing depression and rumination of Isfahan university students. Bimonthly Journal of Scholar Behavior, University of Shahid, No. 34.

Esmailian, N.; Tahmasebian, K.; Dehghani, M. \& Moutabi, F. (2013). Effectiveness of mindfulness based cognitive therapy on depression symptoms and acceptance of children of divorced parents. Journal of Clinical Psychology, Vol. 3, No. 3(19), pp. 47-57.

Farahbakhsh, K. (2009). Study and comparison of illogical beliefs in depressive patients and normal people, Unpublished Master Thesis, Alameh University, Tehran.

Kaviani, H.; Javaheri, F. \& Bahiraie, H. (2009). Effectiveness of mindfulness based cognitive therapy in reducing negative automatic thoughts, inefficient attitudes, depression and anxiety, 60 days follow-up. Journal of Novels in Cognitive Science, Vol. 7, No. 1(25), p. 49.

Khaleghi pour, S. \& Zargar, F. (2011). Effectiveness of mindfulness based cognitive therapy on depression and life hope in mothers of mental retarded children, Journal of Medical School, No. 5, pp. 393-399.

Omidi, A.; Mohammad Khani, P.; Pour Shahbaz, A. \& Dolatshahi, B. (2008). Effectiveness of mixed CBT and $\mathrm{MBCT}$ in reducing accompanied symptoms of major depressive disorder. Research paper.

Omidi, A.; Mohammadi, A.; Zargar, F. \& Akasjeh, G. (2013). Comparison of effectiveness of mindfulness based cognitive therapy mixed with cognitive therapy and classic cognitive behavior therapy in reducing inefficient attitudes of patients with major depressive disorder, Original research paper. 
Teasdale (1997). The relationship between cognition and emotion: Situational mind in mood disorders, In Applied knowledge and methods of cognitive-behavior therapy, translated by H. Kaviani, 2001. Tehran: Cognitive Science Research Institute.

Baer, R.A. (2008). Mindfulness training as a clinical intervention: A conceptual and empirical review. Clinical Psychology: Science and Practice, No. 10, pp. 125-143.

Beck, A.T. '91967). Depression: Clinical, experimental and theoretical aspects. New York: Hoeber.

Beck, J.S. (2011). Cognitive therapy: Basics and beyond ( $2^{\text {nd }}$ ed.). Guilford Press.

Borkovec, T.D. (2007). Life in the future versus life in the present. Clinical Psychology: Science and Practice, No. 9, pp. 76-80.

Broderick, P. (2011). Mindfulness and coping with dysphoric mood: Contrast with rumination and distraction. Cognitive Therapy Research, No. 5(29), pp. 501-510.

Carighead, W.E. (2008). Behavioral and cognitive behavioral psychotherapy. In G. Stricker \& T.A. Widiger (Eds.) \& I.B. Weiner (Editor in chief). Handbook of psychology (Vol. 8): Clinical psychology. NJ: Jone Wiley \& Sons.

Chang, V.Y.; Palesh, O.; Calddwell, R.; Gasgow, N.; Abramson, M.; Luskin, F.; Gill, M.; Burke, A. \& Koopman, C. (2004). The effects of a mindfulness based stress reduction program on stress, mindfulness self-efficacy and positive states of mind. Journal of stress of health, No. 20(3), pp. 141147.

Kabat-Zinn, J. (2008). Coming to our sense: Healing ourselves and the world through mindfulness. New York: Hyperion.

Kaviani, J.; Hatami, N. \& Javaheri, F. (2012). The impact of mindfulness based cognitive therapy on mental health and quality of life in a sub-clinically depressed population. Archives of Psychiatry and Psychotherapy, No. 1, pp. 21-28.

Robins, C.J. (2008). Zen principles and mindfulness practice in dialectical behavioral therapy. Cognitive and Behavioral Practice, No. 9, pp. 50-57.

Schulman, P. (2008). Depression prevention in adults. Schulman@psych.upenn.edu

Siegle, G.J.; Sagrati, S. \& Crawford, C.E. (1999). Effects of rumination and initial severity on response to cognitive therapy for depression. Paper presented at the $33^{\text {rd }}$ annual convention of the Association for Advancement of Behavior Therapy, Toronto, Canada.

Teasdale, J.D. \& Barnard, P.J. (1993). Affect, cognition and change: Re-modelling depressive thought. Hove, UK: Erlbaum.

Teasdale, J.D.; Segal, Z.V. \& Williams, J.M.G. (2003). Mindfulness training and problem formulation. Clinical Psychology: Science and Practice, No. 10(2), pp. 157-160.

Teasdale, J.D.; Segal, Z.V.; Williams, J.M.G.; Ridgeway, V.A.; Soulsby, J.M. \& Lau, M.A. (2000). Prevention of relapse/recurrence in major depression by mindfulness based cognitive therapy. Journal of Counselling and Clinical Psychology, No. 68, pp. 615-623.

Williams, J.M.G.; Duggan, D.S.; Crane, C. \& Fennell, M.J.V. (2006). Mindfulness based cognitive therapy for prevention of recurrence of suicidal behavior. Journal of Clinical Psychology, No. 6(2), pp. 201-210. 